\title{
The Role of Corporate Sustainability Performance for Economic Performance: A Firm-Level Analysis of Moderation Effects
}

\begin{abstract}
Marcus Wagner
Julius-Maximilians University of Würzburg, Stephanstr. 1, 97070 Würzburg, E-mail: marcus.wagner@uni-wuerzburg.de, Tel.: +39-931-318-9046, Fax: +49-931-318-7263 and Bureau d'Economie Théorique et Appliquée, CNRS et Université de Strasbourg, 61 avenue de la Fôret Noire, 68000 Strasbourg CEDEX, E-mail: wagner@ cournot.u-strasbg.fr
\end{abstract}

\begin{abstract}
This paper analyses the link between sustainability management and economic performance. Its main research question of concerns the association of social responsibility and environmental management with economic performance, determinants of the latter and possible moderation effects. Based on data collected from financial databases and Kinder Lydenberg Domini for the period 1992 to 2003, the paper analyses the link of corporate sustainability performance with economic performance using panel estimation techniques. The analysis shows that advertising intensity moderates the association of corporate sustainability performance and economic performance as measured by Tobin's q. For research and development efforts relative to firm size, no moderating role on the link between corporate sustainability and economic performance is identified. A sensitivity analysis using separate measures for social and environmental performance reveals that the latter only has a direct effect and the former only a fully moderated effect on economic performance. Policy and management implications of these findings are discussed.
\end{abstract}

Key words: economic performance, moderation, corporate sustainability, panel estimation Appeared in: Wagner, M. (2010). The role of corporate sustainability performance for economic performance: A firm-level analysis of moderation effects. Ecological Economics, 69(7), $1553-1560$. 


\section{Introduction}

This paper centers on the link between sustainability and economic performance, which is empirically justified by the inconclusive results of extant literature. This issue is particularly relevant from a European point of view given the recent communications and initiatives by the European Commission on corporate social responsibility (CSR) and sustainability. Furthermore, global environmental change emerges in areas as diverse as acid rain, biodiversity, climate change, ozone depletion, hydrological processes and global fisheries and is underpinned by anthropogenic processes such as demographic change, urbanisation, economic development and growth, as well as industrialization, expansion of the global tourism industry and changes in land use. Therefore from a conceptual perspective, there are complex interrelationships between the key drivers of global change and these require global action of multinationals and co-operation between nations to implement effective policies towards sustainable development (Levy, 1997; Levy and Egan, 2003). Because of this and the possible systematization of environmental risks (Figge, 2005) the responses by multinational corporations in terms of corporate social responsibility, corporate citizenship environmental management or corporate governance became a focus of attention in parallel to processes of globalization and offshoring (Levy, 1995; Levy and Prakash, 2003).

Corporate sustainability performance (CSP) is a newly emerging term in this debate about business, the environment and the social responsibility of firms, which aims to address the social, environmental and economic (performance) aspects (i.e. the three pillars) of sustainable development (Takala and Pallab, 2000). It essentially comprises activities relating to CSR and environmental management systems. Given that corporate sustainability has been identified as key to defusing sustainability demands, the question immediately arises how sustainability management can be implemented in ways that at 
least do not jeopardize, and at best even foster, the economic performance of firms (Orlitzky et al., 2003; Orsato, 2006). This is also important because governments often support environmentally and socially beneficial activities with various policy instruments, with the intention to increase international competitiveness and simultaneously support sustainable development (Beise-Zee and Rennings, 2005). The underlying motivation for this, in accordance with the seminal National Bureau of Economic Research volume (Nelson, 1962), is to trigger a change in the direction of qualitatively different innovation. In parallel, firms use CSR and environmental management systems partly in the hope that this will foster such innovation in their organization, and governments frequently support CSR and environmental management systems (EMS) precisely because of this perceived link (Rehfeld et al., 2007 Rennings et al., 2006). The paper analyses this issue by initially reviewing the literature and developing hypotheses based on the underlying theories. It then goes on to present the empirical data and econometric methods used to test these hypotheses. Finally it reports results and derives conclusions based thereon.

\section{Review of literature and hypothesis development}

Regression-based studies are a main approach to assess the relationship between sustainability and economic performance of firms. Economic performance is understood in the context of this research as stock market based measures of financial return. Stock market based measures are preferable to accounting based measures, as the latter are more affected by managerial discretion in the utilization of accounting rules or by periods of heightened inflation and are based on past data, whereas stock market based measures are forward-looking in that they are based on future expected performance (Johnson and Kaplan, 1987; Venkatraman and Ramanujam, 1986; Schipper, 1989). Furthermore it should be acknowledged that financial risk (again measured either by accounting or stock 
market based) is an additional aspect to be taken into account in assessing the link between sustainability and economic performance in a more comprehensive manner (Orlitzky and Benjamin, 2001). However, since no regression-based studies could be identified that simultaneously utilize stock-market based return measures and measures of risk as dependent variables, it was decided to focus initially on return measures only as dependent variables.

Generally regression-based studies constitute advanced, multivariate statistical analyses which are able to assess not only the variance explained by a set of independent variables, but also how influential each individual variable is once its interaction with other control variables is accounted for. In the context of this paper, three studies are of particular relevance as they (like this paper) utilize Tobin's q as an (arguably superior) measure of economic performance that has been used in related contexts (La Porta et al., 2002; Luo and Bhattacharya, 2006).

In the first of these studies, Konar and Cohen (2001) disaggregate the market valuation of corporate environmental performance and attempt to segregate firm-specific effects to assess the role of environmental reputation on market value. To do so, Tobin's q value is regressed against several explanatory and control variables, including an environmental performance. The environmental performance measures adopted by Konar and Cohen were the aggregate mass of emitted toxic chemicals listed in the Toxic Release Inventory (TRI), normalized for size using firm sales and the number of environmental lawsuits pending against a firm.

Using Tobin's q for the year 1989 as dependent variable in a multiple regression model for 321 firms from the S\&P 500, Konar and Cohen find that the included control variables are in sign and significance consistent with the literature. R\&D expenditure, market share, industry concentration, firm growth rates and advertising expenditures are positively 
related to Tobin's q, and firm size is related negatively. Firm size effects were also controlled for through the logarithm of firm assets and industry effects through industry dummy variables.

After accounting for the effects of these variables, environmental performance was found to have a negative effect on Tobin's q, with the effect being stronger for toxic chemicals disclosures in the TRI than for the number of lawsuits pending against a firm. Thus, the results broadly confirm that low environmental performance has a negative effect on market valuation of a firm and also reveals the importance of $R \& D$ and advertising expenditures for economic performance. However, the study does not take into account a possible interaction of environmental performance with advertising and R\&D (which were shown to be relevant individually), as proposed by Hull and Rothenberg (2008). In a second study using Tobin's q as the dependent variable, King and Lenox (2001) analyse the association of TRI emissions with economic performance. They base their analysis on a sample of 652 firms for which financial data from the Compustat database could be matched with TRI emissions data. Controlling for other predictors of Tobin's q such as size of the firm, annual growth of the firm, leverage, R\&D intensity and capital intensity, a negative association is found for TRI emissions and Tobin's q. This finding remains stable regardless of the operationalization of the emissions variable in terms of firm-level emissions or industry emissions and firm-level emissions relative to industry emissions. The study also controls for industry differences by including industry dummies based on the same classification scheme as Konar and Cohen (2001).

The study by King and Lenox is characterized by a number of improvements over the analysis of Konar and Cohen (2001). Most importantly, it utilizes panel data for the period 1987 to 1996 . This enables King and Lenox to use well established random and fixed effects panel models that address whether an unobserved variable is associated with 
Tobin's q and TRI emissions. They find that regardless of which model is involved, the association of TRI emissions remains significant. ${ }^{1}$

As with the study of Konar and Cohen (2001), King and Lenox also find that the results for control variables are consistent with what could be expected from extant literature. Firm size and capital intensity are consistently negatively related to Tobin's q, whereas annual firm growth and R\&D intensity are consistently positively associated with Tobins's q. However, their study also did not address the interaction effects suggested by Hull and Rothenberg (2008), even though their use of panel data makes for a more elaborate analysis compared to Konar and Cohen.

Finally, a third study using Tobin's q as its dependent variable is the analysis of Dowell et al. (2000). Their analysis addresses whether the implementation of global environmental management standards increases firm value. Based on a sample of 89 multinational US firms (as defined based on majority ownership) in the manufacturing and mining industries, they construct a panel data set covering the years between 1994 and 1997 and find that the implementation of international environmental standards is positively associated with Tobin's q.

Dowell et al. (2000) interpret from their results that developing countries who attempt to attract foreign direct investment with less stringent environmental regulation run the risk of attracting less competitive firms. Based on their findings, Dowell et al. (2000) identify additional research needs with regard to when firms might opt to implement their own environmental management standards, more demanding than generic standards, and how an optimal corporate standard would look.

\footnotetext{
${ }^{1}$ In terms of their measure of environmental performance, both studies reviewed so far use the same base data (TRI emission), however in different specifications. Whilst this increases to some degree the confidence in the (relatively similar) findings, it also has to be noted, that pure emission data are a relatively limited indicator for the totality of activities that firms pursue to improve their corporate sustainability performance.
} 
With their analysis, Dowell et al. (2000) point to the possibility that the relationship between economic performance and environmental (or more broadly corporate sustainability performance) performance might be linked to the level of environmental technology adopted by the firm. However, they did not test directly for this aspect, which they could have done by interacting R\&D expenditure (which they involve as a control variable) of a firm with its environmental performance. ${ }^{2}$

In line with the numerous regression-based studies on the link between corporate sustainability and economic performance (for systematic overviews see e.g. Margolis and Walsh, 2003; Orlitzky et al., 2003.), the three empirical analyses discussed above that matter most for this analysis all suggest positive impulses from social and environmental performance on the economic performance of firms. Therefore the following hypothesis is proposed:

Hypothesis 1: There is a positive association of corporate sustainability performance with economic performance (as measured by Tobin's q).

Building on predecessors of the studies discussed above, McWilliams and Siegel (2000) have argued that omitted variable bias occurs if $R \& D$ and advertising intensities are not taken into account as a predictor for economic performance. They argue that this is because the market value of a firm can be separated into its tangible asset value (estimated from accounting values and replacement costs) and its intangible asset value (patents, trademarks, proprietary raw material sources, brand/name reputation and firm goodwill). The intangible asset value in these significantly depends on advertising and $R \& D$ expenditures relative to sales (Scholtens, 2008). McWilliams and Siegel (2000) confirm this line of argument empirically, by showing that the addition of measures for R\&D and

\footnotetext{
${ }^{2}$ The measure of environmental performance that Dowell et al. use is not based on emission levels, as were those utilised by Konar and Cohen (2001) and King and Lenox (2001). Hence a direct comparison is more difficult.
} 
advertising intensities in an earlier model proposed by Waddock and Graves (1997) renders insignificant the association of corporate social performance with economic performance, which in the original study was significant, Although the empirical exercise in McWilliams and Siegel (2000) illustrates the issue, it does not involve panel estimation methods, but only analyses cross-sectional data by calculating average values for all variables over the period from 1991 to 1996 . Calculating such averages should reduce issues arising from strong fluctuations of firm-level data over time but it does not address omitted variable bias since averages do not allow accounting for unobserved heterogeneity in the same way as panel estimation methods.

Hull and Rothenburg (2008) in a recent study expand the line of argument developed by McWilliams and Siegel (2000) by suggesting that next to the need for incorporating advertising and R\&D intensities in any analysis of the link between economic and corporate sustainability performance (with the latter comprising the effects of both, CSR as well as environmental management aimed at reducing emissions and saving resources), it is also necessary to account for the interaction of advertising and $R \& D$ with sustainability performance. Hull and Rothenberg (20089) argue that the association of sustainability with economic performance depends on firms' ability to differentiate their offerings, which is moderated by innovation activities and the level of advertising. Their study of a dataset combining Kinder Lydenberg Domini (KLD) rating data with Compustat firm-level data after excluding all entries with missing data analyses 69 firms for which complete data were available for the years from 1998 through 2001. Very similar to McWilliams and Siegel (2000), for these firms they calculate weighted averages of all independent and control variables over the period from 1998 through 2000 . These average values were then regressed on economic performance; this is a serious limitation because the 69 firms are significantly fewer than would be possible based on the initial matching 
between KLD and Compustat data. My analysis, for example, based on the same matching approach, comprises 358 firms because it makes use of the panel structure of the data.

Given this, selection bias is very likely for the data set used in Hull and Rothenberg (2008). Furthermore, the latter do not involve panel estimation methods, even though the four years of observations they had available would have allowed them to do so. They are therefore faced with the same limitation as McWilliams and Siegel (2000) and thus also cannot rule out problems related to unobserved heterogeneity. Against the backdrop of these limitations, their analysis finds that both innovation and differentiation as measured by advertising intensity are moderators for a positive relationship between an index based on KLD data and economic performance.

Following the call of Hull and Rothenberg (2008) for more complex models, and the argument of McWilliams and Siegel (2000) to account for R\&D and advertising activities of firms, the interaction of the latter two with CSP needs to be considered in more detail. R\&D efforts of a firm have been argued at least since Schumpeter $(1934,1943)$ to be an important predictor of economic performance and firm growth (see also Burns \& Stalker, 1961; Utterback, 1994; Christensen, 1997). Christensen (1997) shows that in the face of disruptive innovation, $R \& D$ efforts are pivotal even for the basic survival of the firm. Teece et al. (1997) relate this to the resource-based view. Both arguments imply that specific competences and capabilities matter to ensure that $R \& D$ efforts contribute to economic performance and are not easily imitated. CSP can be one such capability. For example, Rennings et al. (2006) find that the implementation level of environmental management activities is one important determinant of innovation activities that create environmental benefits. Avadikyan et al. (2001) relate this to organizational learning processes and therefore the development of capabilities that are hard to imitate and so constitute a strategic resource in the sense of the resource-based view (Mackey et al., 
2007). Hence the interaction of R\&D and CSP seems to be crucial as a factor affecting the economic performance of firms.

Providing feedback to the customers, regulators and other interested stakeholders about the environmental quality and social benefits of products and processes through information dissemination, labelling and other means of signalling increasingly becomes important for firms to realize economic benefits (Boer, 2003; Karl \& Orwat, 1999; Riley, 2001). Advertising is both a means of differentiation and a way of providing information about CSP, and hence amplifies the effects of CSP (Shapiro, 1983; Fisman et al., 2008). For example, high levels of CSP can enable a firm to make use of labelling schemes that signal specific product qualities (including credence goods) and hence support product differentiation (Kirchhoff, 2000; Feddersen \& Gilligan, 2001)). In doing so, they help to capture customers willingness-to-pay for CSP and support the choice and self-selection of suitable cooperation partners in the supply chain by circumventing issues of adverse selection and moral hazard, ultimately enabling the realization of more complex innovations that are difficult to imitate and hence potentially constitute a strategic resource. Turban and Greening (1997) show, that signalling high levels of CSP enables firms to recruit more innovative and motivated employees, which can impact positively on economic performance. To the degree that environmentally concerned employees selfselect themselves into appropriate firms, labelling and other advertising activities aimed at signalling high levels of CSP enable a firm to strengthen a reputation of endorsing corporate sustainability and (e.g. by hiring environmentally concerned employees) to create a strategic resource that supports better differentiation and, ultimately, better economic performance. Based on these considerations, two additional hypotheses can be proposed: 
Hypothesis 2: Corporate sustainability performance impacts economic performance more positively in low innovation firms (as measured by $R \& D$ intensity) than it does in highinnovation firms.

Hypothesis 3: Corporate sustainability performance impacts economic performance less positively in firms with low levels of differentiation and signalling (as measured by advertising intensity) than it does in firms with high levels of differentiation and signalling.

My analysis in the following draws upon the body of extant literature in the analysis of the link between economic and corporate sustainability performance in terms of testing the increasingly refined hypotheses derived from this earlier work in an holistic manner. In doing so however, it mitigates a number of individual weaknesses of each of the studies discussed above. First, I use panel data and also apply panel models in the econometric analysis to account as fully as possible for unobserved heterogeneity, as do Konar and Cohen (2001) and King and Lenox (2001). Furthermore, I involve a very broad measure to gauge corporate sustainability performance beyond pure emission data while accounting for the need to incorporate R\&D and advertising intensities and their interaction with CSP, as suggested by McWilliams and Siegel (2000) and Hull and Rothenberg (2008).

\section{Data and Method}

The empirical analysis of the hypotheses derived in the previous section uses panel data for a set of US firms. As noted earlier, the advantage of panel data is that unobserved heterogeneity is not a problem, since panel estimation techniques largely capture its effects. Furthermore, using panel data enables the inclusion of lagged values, which reduces endogeneity problems and issues regarding assumed directions of causality that arise from contemporary independent and independent variables. 
The set of firms in the Standard \& Poor's 500 index as of 31 July 2003 was used to define the sample of firms to be analysed. The main sources from which data were collected were the Compustat and Worldscope Disclosure and BankerOne databases and the ratings of corporate social responsibility and environmental management carried out by KLD. The KLD database contains detailed annual ratings on the environmental and social activities and performance of over 600 of the largest US companies. The data is available for a period of over ten years and enables a detailed assessment of firms' activities with regard to the environment and to social issues. It is also one of the most reputed sources for scholarly studies in the field of stakeholder management (see Waddock and Graves, 1997; McWilliams and Siegel, 2000). Given that the data is collected and aggregated by independent analysts, issues of social desirability that frequently surround empirical work on corporate sustainability (especially in the case of self-evaluation in the context of surveys) are much less pronounced with the KLD data. After matching KLD data with financial and organisational data from the other sources, 3697 usable cases remained for the period 1992 to 2003, for which data were however not always available on all variables included in the analysis. The final sample on which estimations are performed includes therefore only 2478 observations.

As concerns the dependent variable measuring economic performance, Tobin's q was chosen, which takes the value of unity for firms without intangible assets and is closely related to the ratio between the tangible and intangible asset values. As a market-based, rather than accounting-based measure of economic performance, it is superior to measures such as return on assets or on equity. Tobin's q is measured as the logarithm to the base of ten of the ratio of market value of a firm over its replacement costs.

As the main independent variable, as suggested by Ullmann (1985) an overall corporate sustainability performance index was calculated comprising all KLD strengths and 
concerns that were available for all years from 1992 through to 2003. This index is based on Waddock and Graves (1997), Dyer and Whetten (2006) and Hull and Rothenberg (2008) who also provide more descriptive information on the index. As detailed in Hull and Rothenberg (2008), the index essentially measures the totality and hence the extent of all activities related to CSR and environmental management (positive or negative) for a firm in any given year. The index ranges from 0 to 19 with a mean value of 10.1 . It approximates specific competencies and capabilities (or lack thereof) that are developed as a result of specific activities relating to social responsibility and environmental management and it can thus be understood as a measure of overall corporate sustainability. In addition to this, it has been argued (Gerde and Logsdon, 2001) that aggregating a number of aspects relating to CSR and environmental management points to an underlying trait representing activities that directly or indirectly benefit society, as they should be reflected in any measure of corporate sustainability performance.

Furthermore, Hull and Rothenberg (2008) validate the robustness of this index based on KLD data by showing that different variants of such an index produce the same empirical relationships as were found in earlier studies, notably those of Waddock and Graves (1997) and McWilliams and Siegel (2000).

Although the reliability and validity of the index described can be considered proven from extant literature, the different categories in which KLD strengths and concerns are evaluated (natural environment, characteristics of the firm's products, community aspects, diversity issues, employee relations, human rights concerns and corporate governance) can be considered rather diverse. Therefore, based on these categories, two sub-indices for corporate environmental and social performance were derived. Whereas the environmental sub-index relates to the first two categories above and ranges from 0 to 8 with a mean value of 4.6, the social sub-index ranges from 0 to 11 with a mean of 5.5. As a sensitivity 
analysis and also to gauge better the separate economic impact of corporate environmental and social performance, all estimations are also done with these variant variables instead of the corporate sustainability performance index.

As concerns the variation of the three indices over the period of 1992 to 2003, the overall change of the mean scores across the whole period was $-1.1 \%$ for social, $-3.4 \%$ for environmental and $-4.3 \%$ for corporate sustainability performance. Analysing year-on-year changes it is found that for corporate environmental performance, these range from $4.0 \%$ to $1.5 \%$, with the absolute values of the index ranging from 4.4 to 4.8 across the period analysed. As concerns corporate social performance, absolute values oscillate between 5.3 to 6.0 and year-on-year changes of the index take values between $-5.4 \%$ and $5.0 \%$. Finally, as concerns the corporate sustainability index, values range from 9.8 to 10.8 and year-onyear percentage changes from $-3.4 \%$ to $3.2 \%$. Overall, although these figures are consistent with the standard deviations of the indices and thus suggest that temporal intertia is relatively strong, they also confirm the existence of variation that after controlling for other factors can affect Tobin's q of the firms analysed.

Next to the above dependent and independent variables, a number of additional variables have been included based on a review of extant literature especially in industrial economics (Scherer, 1992; Schmalensee, 1989). These include firm age (measured as the number of years since the firm was founded), firm size (measured as the value of assets) as suggested by Johnstone and Labonne (2009), and also the square of firm size as suggested in Hemmelskamp (1999). As the distribution of some variables, such as firm age and size, was highly skewed, logarithmic values of these were used in the empirical analysis. Also R\&D intensity measured as R\&D expenditure divided by sales (as one central moderator variable) and sales growth over the prior year as suggested in Horbach (2008) were included in the analysis. Furthermore advertising intensity (as the other central 
moderator variable) and a variable measuring if a firm has a quality management system as a signal (Terlaak and King, 2006) for a quality-oriented, rather than cost-oriented strategy of a firm (which should be associated with increased intangible value) are included as control variables. All explanatory variables introduced are lagged by one year (i.e. are for $\mathrm{t}-1)$ in the analysis to avoid problems of endogeneity. ${ }^{3}$

Industry membership as measured based on two-digit SIC industry categories, as well as time dummies for each year in the data (1992 to 2003) were included as non-time lagged variables. Finally, interaction terms of advertising and R\&D intensity with corporate sustainability performance and the two sub-indices for environmental and social performance, respectively, were introduced in the model to address the second and third hypothesis. Given that separate estimations for the (joint) sustainability and (environmental and social) sub-indices had to be carried out, four variants of the model were estimated (of which two include interaction terms for sustainability and social/environmental performance, respectively). The appendix summarizes correlations and descriptive statistics for the relevant variables.

All estimations were implemented in the STATA 9.0 software. Given that a number of relevant variables are time-invariant, in keeping with the literature (e.g. Dyer and Whetten, 2006) a random effects panel model was estimated according to the basic equation (1):

$$
y_{i t}=\alpha+\vec{\beta} \cdot \vec{x}_{i t}+\vec{\imath} \cdot \vec{z}_{i}+u_{i t}
$$

In (1) $i$ equalling 1 to $\mathrm{N}$ refer to the units under observation and $t$ equalling 1 to $\mathrm{T}$ refers to the time periods in the data (1992 to 2003). $y_{\text {it }}$ is the value of the dependent variable

\footnotetext{
${ }^{3}$ I considered instrumentalizing the sustainability performance measure with data on important regulatory changes in the U.S. in order to improve the quality of the estimation procedure. However, all significant social and environmental regulation in the U.S. that could have triggered an increase in the level of disclosure or external assessment of the firms social and environmental management activities took place before 1993. Hence an instrumental variables approach was not possible.
} 
(Tobin's q) for firm $\mathrm{i}$ in period t. $\mathrm{x}_{\mathrm{it}}$ is the vector of time-variant variables and $\mathrm{z}_{\mathrm{i}}$ the vector of time-invariant variables such as industry dummies. In the following, the results of the analysis are reported and conclusions drawn from these.

\section{Results}

To assess concerns with regard to sample selectivity, a Heckman selection model (Heckman, 1976) was estimated with the selection variable being whether or not an observation was included in the multivariate analysis (i.e. whether data on all variables included in the analysis were available).

However, the (nonsignificant) lambda value of -0.229 (which is the inverse of the Mills' ratio and represents the selection hazard) and the rho value of -0.144 (reflecting the (nonsignificant) correlation of the residuals in the two equations) suggest that this is not the case. For reasons of brevity therefore only results for the one-step random effects model are reported.

The fact that most control variables are nonsignificant is probably due to the inclusion of temporal and industry effects and of lagged growth as an explanatory variable in the model. ${ }^{4}$ Testing for the joint significance of the industry and year dummy variables reveals that the respective Chi-squared test statistics are all highly significant and hence confirms the interpretation that these variables account for much of the variation in the dependent variable, in turn rendering the other control variables largely insignificant.

As concerns the first hypothesis, Table 1 shows that both are supported by the analysis. The rho value at the bottom of Table 1 (which can be understood as that proportion of total variance which is contributed by the firm level variance component) indicates that this

\footnotetext{
${ }^{4} \mathrm{I}$ am grateful to one reviewer pointing this out to me.
} 
variance component is important and that hence a pooled model would be inappropriate, since there is unobserved heterogeneity present in the data.

Insert Table 1 about here

Concerning the second and third hypothesis, whereas the second hypothesis is not supported in the analysis, the third hypothesis that the effect of corporate sustainability performance on Tobin's q is moderated by advertising intensity finds support, as can be seen in Table 2. From the table it becomes clear that whereas having high advertising intensity or high corporate sustainability performance alone does not affect Tobin's q, the interaction of both is significantly and positively associated with economic performance.

Insert Table 2 about here

Given that a significant interaction was identified between advertising intensity and corporate sustainability performance, further visual exploration (Jose, 2008) is deemed useful and is done in Figure 1. It shows the effect corporate sustainability performance has on Tobin's q for three different levels of advertising intensity (high, medium, and low). The three levels are calculated at the mean as the medium value, as well as one standard deviation above the mean as the high, and one standard deviation below the mean as the low value (Aiken and West, 1991). As Figure 1 reveals, for low levels of advertising intensity, corporate sustainability performance has only a negligible effect on Tobin's q. This can be explained by the fact, that without publicizing efforts related to corporate sustainability, it is unlikely for firms to benefit from these for example in terms of heightened demand. 
Insert Figure 1 about here

The effect of corporate sustainability performance on Tobin's q is largest for high levels of advertising intensity, whereas for medium levels of advertising intensity, the association is less strong than for high, but clearly stronger than for low advertising intensity. As concerns the sensitivity analysis based on the two sub-indices for corporate environmental and social performance, the results in Table 1 reveal that without considering interaction effects, both have the expected relationship with economic performance, that is, both sub-indices are significantly positively associated with Tobin's q. This essentially supports the first hypothesis.

Including the interaction effects (in this case two each for R\&D and advertising intensity, with, respectively, corporate social and corporate environmental performance) alters the results in that, as is revealed in Table 2, corporate environmental performance only has a significant direct positive effect whereas corporate social performance only has a fully moderated (positive) effect on economic performance by way of advertising intensity. As concerns the moderation effect, Figure 2 reveals that corporate social performance affects Tobin's q most strongly for high levels of advertising intensity, whereas for medium levels of advertising intensity, the association is less strong than for high, but clearly stronger than for low advertising intensity. Comparing the steepness of the slopes for different levels of sustainability respectively social performance between Figures 1 and 2 indicates that the moderation effect is more pronounced for the interaction of corporate social performance and advertising, than it is for corporate sustainability performance. This is of course as expected, since the latter performance measure also includes elements of 
environmental performance, which were shown not to be moderated by advertising intensity.

Insert Figure 2 about here

\section{Conclusions and Discussion}

To conclude, this paper addressed three hypotheses on the linkages between corporate sustainability, innovation and economic performance. Table 3 provides an overview of the results with respect to testing these hypotheses.

Insert Table 3 about here

Although the hypotheses are largely supported, with regard to innovation it should be noted that it seems not to interact with corporate sustainability performance. The analysis reveals, that innovation activities do not per se improve the effect of corporate sustainability (as is witnessed by the nonsignificant interaction of the two). Innovation is also not found to be significant as a factor in its own right to associate with economic performance. Therefore, it seems that a positive contribution of innovation to corporate sustainability requires a change in the direction of inventive activity, as is proposed for example by Rennings (2000).

Still, a microeconomic relationship between innovation and economic performance can and cannot be fully ruled out based on these results. First of all, my analysis operationalizes innovation in terms of (relative) $R \& D$ exependitures and hence focusses largely on technological innovation. However a variety of innovation forms exist and it may be that the operationalization used in this paper does not pick up all of them. Given 
this large variety, even the use of other established indicators of innovation such as patents might not change the findings, however, in the case of service innovation, for example. Still, future research should put the role of different forms of innovation to an empirical test.

The notion that firms are constrained to a specific technological paradigm that hinders pursuance of novel forms of innovation activities and at the same time constrains the trajectories firms can pursue towards more incremental and thus potentially sub-optimal solutions (Dosi, 1982) also provides an interesting perspective on how firms can innovate strategically for sustainability, as is often proposed or at least desired by politicians (see also the discussion above in the introduction of this paper). From an evolutionary perspective, however, this seems to be more a co-evolutionary process (Noailly, 2008), given that the development of a firm's knowledge base is an historic and evolutionary process that may involve irreversible decisions about technologies, market focus or other parameters and in this sense is path-dependent. An important implication for policy from this is that innovating for sustainability may not be as strategically feasible as is demanded. This situation can be ultimately understood as a co-evolving system of regulatory demands (i.e. institutional factors) and knowledge needed to meet these demands in which both aspects need to be in a balance for the system to function (see North, 1990: 78). To some degree this seems to indicate also that the co-evolution of industry structure and technology, understanding and practice (Nelson and Winter, 2002) and the consequences of these for institutions and innovation systems should be analysed further in future research, especially with regard to performance implications. Finally, a notable finding from this study is, that (corporate) sustainability, when determining economic performance at the firm level, is moderated by the differentiation focus and advertising intensity of a firm. This links with extant work linking differentiation 
strategies and reputation building based on social responsibility (Waldman et al., 2006). Therefore, future research should attempt to use these variables directly to analyse interaction effects and to confirm the results of this study.

As an additional contribution of this research, a sensitivity analysis splitting the corporate sustainability performance into two components relating social and environmental performance reveals that the latter only has a direct effect and the former only a fully moderated effect on economic performance by way of advertising intensity.

This finding is consistent with the results of Ziegler et al. (2007) indicating a potential trade-off between corporate social performance and economic performance. Corporate social performance seems only to associate positively with the latter if a firm reaches a sufficiently high level of advertising that enables a certain level of diffusion of the knowledge about its socially-related activities to relevant stakeholders such as consumers, non-governmental groups or regulatory agencies. If the firm does not develop this complementary element to its social responsibility activities, then these seem to have negative net benefits, that is, without sufficient advertising, the cost for social responsibility activities exceeds benefits, which is an important managerial implication. Furthermore, it highlights for policymakers the need to consider the possibility of subsidizing advertising activities as the moderating factor, rather than socially-related activities themselves. The reason is that doing only the latter may ultimately not suffice to encourage firms to implement social responsibility activities if they are not in a position to realize net benefits out of this.

Conversely, the results for corporate environmental performance are in keeping with most of the extant literature on this topic, which finds that efficiency gains, as well as other factors such as risk reduction, lead to a direct positive effect on economic performance. 
This insight should be a relief to managers concerned about such direct effects, since it confirms insights from earlier studies.

The main conclusion of my research seems to be the insight that moderation affects matter and that it is indispensable to consider these in future studies both in,conceptual arguments and in empirical analyses, to ensure a fuller and improved understanding of the link between sustainability management and economic performance.

\section{Acknowledgements}

I am grateful to Thomas Lücking for valuable comments on this paper and to Jörn Block for sharing data gathered from the FEDC of the German Science Foundation project SFB 649 "Economic Risk" with me that formed part of the data used in the analysis. All remaining errors are mine.

\section{References}

Aiken, L.S., West, S.G., 1991. Multiple regression: Testing and interpreting interactions. Newbury Park (CA): Sage.

Avadikyan, A., Llerena, D., Ostertag, K., 2001. Organisational mechanisms in environmental management: an evolutionary analysis confronted with empirical facts. International Journal of Environmental Technology and Management, 1(12): 45-60.

Beise-Zee, M., Rennings, K., 2005. Lead Markets and Regulation: A Framework for Analyzing the International Diffusion of Environmental Innovation. Ecological Economics, 52(1): 5-17.

Boer, J. de, 2003. Sustainability labelling schemes: the logic of their claims and their functions for stakeholders. Business Strategy and the Environment, 12(4): 254-264. 
Burns, T., Stalker, G.M., 1961. The Management of Innovation. London (UK): Tavistock Institute.

Christensen, C., 1997. The Innovator's Dilemma. Boston (MA): Harvard Business School Press.

Dosi G., 1982. Technological paradigms and technological trajectories. Research Policy, 11: $147-162$.

Dowell, G., Hart, S.L., Yeung, B., 2000. Do Corporate Global Environmental Standards Create or Destroy Market Value? Management Science, 46(8): 1059-1074.

Dyer, W.G., Whetten, D.A., 2006. Family firms and social responsibility: preliminary evidence from the SandP 500. Entrepreneurship Theory and Practice, 30(6): 785-802. Feddersen, T.J., Gilligan, T.W., 2001. Saints and Markets: Activists and the Supply of Credence Goods. Journal of Economics and Management Strategy, 10: 149-171. Figge, F., 2005. Value-based environmental management. From environmental shareholder value to environmental option value. Corporate Social Responsibility and Environmental Management, 12(1): 19-30.

Fisman, R., Heal, G., Nair, V.B. 2008. A Model of Corporate Philanthropy (working paper). New York (NY): Columbia University.

Gerde, V., Logsdon, J., 2001. Measuring environmental performance: use of the Toxics Release Inventory (TRI) and other environmental databases. Business Strategy and the Environment, 10(5): 269-285.

Heckman, J., 1976. The Common Structure of Statistical Models of Truncation, Sample Selection and Limited Dependent Variables and a Simple Estimator for Such Models. Annals of Economic and Social Measurement, 5(4): 475-492. 
Hemmelskamp, J., 1999. Umweltpolitik und technischer Fortschritt. Eine theoretische und empirische Untersuchung der Determinanten von Umweltinnovationen. Heidelberg: Physica.

Horbach, J., 2007. Determinants of environmental innovation: New evidence from German panel data sources. Research Policy, 37: 163-173.

Hull, C.E., Rothenberg, S., 2008. Firm Performance: The Interactions of Corporate Social Performance with Innovation and Industry Differentiation. Strategic Management Journal, 29: 781-789.

Johnson, H.T., Kaplan, R.S., 1987. Relevance Lost: the Rise and Fall of Management Accounting. Boston, MA: Harvard Business School Publishing.

Johnstone, N., Labonne, J. 2009. Why do manufacturing facilities introduce environmental management systems? Improving and/or signaling performance. Ecological Economics, 68: $719-730$

Jose, P.E., 2008. ModGraph-I: A programme to compute cell means for the graphical display of moderational analyses: The internet version (Version 2.0, Wellington, Victoria University of Wellington). Retrieved January 5, 2009, from http://www.victoria.ac.nz/psyc/staff/paul-jose-files/modgraph/modgraph.php. Karl, H., Orwat, C., 1999. Economic aspects of environmental labeling. In: Folmer, H., Tietenberg, T. (Eds.), The International Yearbook of Environmental and Resource Economics 1999/2000. Edward Elgar, Cheltenham (UK), pp. 107-170.

King, A., Lenox, M., 2001. Does it Really Pay to be Green? Accounting for Strategy Selection in the Relationship between Environmental and Financial Performance. Journal of Industrial Ecology, 4(4): 105-116. 
Kirchhoff, S., 2000. Green Business and Blue Angels: A Model of Voluntary Overcompliance with Asymmetric Information Environmental and Resource Economics, 15: 403-420.

Konar, S., Cohen, M.A., 2001. Does the Market Value Environmental Performance? Review of Economics and Statistics, 83(2): 281-289.

La Porta, R., Lopez-de-Silanes, F., Shleifer, A., Vishny, R., 2002. Investor Protection and Corporate Valuation. Journal of Finance, 57(3): 1147-1170.

Levy, D.L., 1995. The environmental practices and performance of transnational corporations. Transnational Corporations, 4(1): 44-67.

Levy, D.L., 1997. Business and International Environmental Treaties: Ozone depletion and climate change. California Management Review, 39(3): 54-71.

Levy, D.L., Egan, D., 2003. A Neo-Gramscian Approach to Corporate Political Strategy: Conflict and Accommodation in the Climate Change Negotiations. Journal of Management Studies, 40(4): 803-829.

Levy, D.L., Prakash, A., 2003. Bargains Old and New: Multinational Corporations in Global Governance. Business and Politics, 5(2): 131-150.

Luo, X., Bhattacharya, C.B., 2006. Corporate Social Responsibility, Customer Satisfaction, and Market Value. Journal of Marketing, 70(1): 1-18.

Mackey, A., Mackey, T.R., Barney J., 2007. Corporate social responsibility and firm performance: investor preferences and corporate strategies. Academy of Management Review, 32(3): 817-835.

Margolis, J.D., Walsh, J.P., 2003. Misery Loves Companies: Rethinking Social Initiatives by Business. Administrative Science Quarterly, 48(2): 268-305. 
McWilliams, A., Siegel, D., 2000. Corporate Social Responsibility and Financial Performance: Correlation or Misspecification? Strategic Management Journal, 21(5): 603609.

Nelson, R.R., 1962. The rate and direction of inventive activity. Princeton: Princeton University Press.

Nelson, R.R., Winter, S.G., 2002. Evolutionary theorizing in Economics. Journal of Economic Perspectives, 16(2): 23-46.

Noailly, J., 2008. Co-evolution of economic and ecological systems. Journal of Evolutionary Economics, 16: 435-472.

North, D.C., 1990. Institutions, Institutional Change and Economic Performance.

Cambridge: Cambridge University Press.

Orlitzky, M., Benjamin, J. D., 2001. Corporate Social Performance and Firm Risk: A Meta-Analytic Review. Business and Society, 40: 369 - 396.

Orlitzky, M., Schmidt, F.L., Rynes, S.L., 2003. Corporate Social and Financial Performance: A Meta-analysis. Organization Studies, 24(3): 403-441.

Orsato, R., 2006. Competitive Environmental Strategies: When Does It Pay to be Green? California Management Review, 48(2): 127-143.

Rehfeld, K.M., Rennings, K., Ziegler, A., 2007. Integrated Product Policy and Environmental Product Innovations: An Empirical Analysis. Ecological Economics, 61(1): 91-100.

Rennings, K., 2000. Redefining Innovation - Eco-Innovation Research and the Contribution from Ecological Economics. Ecological Economics, 32(2): 319-332. Rennings, K., Ziegler, A., Ankele, K., Hoffmann, E., 2006. The Influence of Different Characteristics of the EU Environmental Management and Auditing Scheme on Technical 
Environmental Innovations and Economic Performance. Ecological Economics, 57(1): 4559.

Riley, J.G., 2001. Silver signals: twenty-five years of screening and signalling. Journal of Economic Literature 39: 432-479.

Schmalensee, R., 1989. Inter-Industry Studies of Structure and Performance, in:

Schmalensee, R., Willig, R.D. (Eds.), Handbook of Industrial Organization - Volume II, Elsevier, Amsterdam (NL), pp. 951-1009.

Schumpeter, J., 1934. The Theory of Economic Development. Cambridge (MA): Harvard University Press.

Schumpeter, J., 1943. Capitalism, Socialism and Democracy. New York (NY): Harper.

Scholtens, B., 2008. A note on the interaction between corporate social responsibility and financial performance. Ecological Economics, 68(2): 46-55.

Scherer, F.M., 1992. Schumpeter and Plausible Capitalism. Journal of Economic Literature, XXX: 1416-1433.

Schipper, K., 1989. Commentary on earnings management. Accounting Horizons, December: 91-102.

Shapiro, C., 1983. Premiums for High Quality Products as Returns to Reputations. Quarterly Journal of Economics, 98(4): 659-679.

Takala, T., Pallab, P., 2000. Individual, collective and social responsibility of the firm. Business Ethics: A European Review, 9(2): 109-118.

Teece, D.J., Pisano G., Shuen A., 1997. Dynamic capabilities and strategic management. Strategic Management Journal, 18(7): 509-533.

Terlaak, A., King, A.A., 2006. The effect of certification with the ISO 9000 quality management standard: a signaling approach. Journal of Economic Behaviour and Organization, 60: 579-602. 
Turban, D.B., Greening, D.W., 1997. Corporate social performance and organizational attractiveness to prospective employees. Academy of Management Journal, 40(3): 658673.

Utterback, J.M. 1994. Mastering the Dynamics of Innovation. Boston: Harvard Business School Press.

Venkatraman, N., Ramanujam, V., 1986. Measurement of business performance in strategy research: A comparison of approaches. Academy of Management Review, 11: 801-814.

Waddock, S.A., Graves, S.B., 1997. The Corporate Social Performance - Financial Performance Link. Strategic Management Journal, 18(4): 303-319.

Waldman, D.A., Siegel, D., Javidan, M., 2006. Components of transformational leadership and corporate social responsibility. Journal of Management Studies, 43(8): 1703-1725. Ziegler, A., Schröder, M., Rennings, K. (2007), The Effect of Environmental and Social Performance on the Stock Performance of European Corporations. Environmental and Resource Economics, 37: 661-680. 
TABLE 1: Quantitative link of Tobin's q and corporate sustainability performance

\begin{tabular}{|c|c|c|}
\hline Explanatory variables and fit statistics for & Dependent variable & Tobin's q \\
\hline random effects model with ... performance: & sustainability & social \& environmental \\
\hline Log. Sales (USD) in $\mathrm{t}-1$ & $0.0162(1.158)$ & $-0.0458(0.804)$ \\
\hline Square log. Sales (USD) in $\mathrm{t}-1$ & $-0.003(0.026)$ & $-0.002(0.026)$ \\
\hline $\mathrm{R} \& \mathrm{D}$ quota in $\mathrm{t}-1$ & $-0.067(0.092)$ & $-0.086(0.059)$ \\
\hline Corporate sustainability performance in $\mathrm{t}-1$ & $0.068(0.018) * * *$ & - \\
\hline Corporate social performance in $\mathrm{t}-1$ & - & $0.083(0.023) * * *$ \\
\hline Corporate environmental performance in $\mathrm{t}-1$ & - & $0.098(0.028) * * *$ \\
\hline Growth in $\mathrm{t}-1$ & $0.007(0.003) * * *$ & $0.007(0.002)^{* * *}$ \\
\hline Log. Firm age in $\mathrm{t}-1$ & $-0.110(0.114)$ & $-0.110(0.115)$ \\
\hline Advertising intensity (\%) in $\mathrm{t}-1$ & $5.808(4.611)$ & $6.010(4.602)$ \\
\hline QMS in $\mathrm{t}-1$ & $-0.080(0.120)$ & $-0.097(0.121)$ \\
\hline Constant & $2.075(13.069)$ & $2.319(11.852)$ \\
\hline Industry dummy variables (joint significance) & $197.42 * * *$ & $194.37 * * *$ \\
\hline Year dummy variables (joint significance) & $283.85 * * *$ & $280.59 * * *$ \\
\hline No. of obs. (min./mn./max./firm), no. of firms & $2478(1 / 6.9 / 11), 358$ & $2478(1 / 6.9 / 11), 358$ \\
\hline Wald chi ${ }^{2}$ & $610.42 * * *$ & $640.74 * * *$ \\
\hline Rho & 0.576 & 0.578 \\
\hline $\mathrm{R}^{2}$ & 0.260 & 0.262 \\
\hline
\end{tabular}


TABLE 2: Quantitative link of Tobin's q and corporate sustainability performance taking into account interaction effects with innovation and differentiation

\section{Explanatory variables and fit statistics for}

random effects model with ... performance:

\section{Dependent variable: Tobin's q} sustainability social \& environmental

Log. Sales (USD) in t-1

Square log. Sales (USD) in t-1

$\mathrm{R} \& \mathrm{D}$ quota in $\mathrm{t}-1$

Corporate sustainability performance in $\mathrm{t}-1$

Corporate social performance in $\mathrm{t}-1$

Corporate environmental performance in $\mathrm{t}-1$

Growth in $\mathrm{t}-1$

Log. Firm age in t-1

Advertising intensity (\%) in $\mathrm{t}-1$

QMS in $\mathrm{t}-1$

R\&D quota $x$ corporate sustainability

performance in $\mathrm{t}-1$

$\mathrm{R} \& \mathrm{D}$ quota $\mathrm{x}$ corporate social performance in $\mathrm{t}-1$

$\mathrm{R} \& \mathrm{D}$ quota $\mathrm{x}$ corporate environmental performance in $\mathrm{t}-1$

Advertising intensity x corporate sustainability

performance in $\mathrm{t}-1$

Advertising intensity $\mathrm{x}$ corporate

social performance in $\mathrm{t}-1$

Advertising intensity x corporate environmental

performance in $\mathrm{t}-1$

Constant

$0.040(1.149)$

$-0.002(0.025)$

$-0.067(0.092)$

$0.023(0.023)$

$0.007(0.002)^{* * *}$

$-0.117(0.113)$

$-22.142(14.887)$

$-0.095(0.121)$

$-5.290(4.837)$

$-0.252(0.807)$

$0.004(0.026)$

$-0.137(0.558)$

$-0.040(0.031)$

$0.157(0.050)^{* * *}$

$0.007(0.002)^{* * *}$

$-0.110(0.113)$

$-13.826(15.216)$

$-0.104(0.123)$

$-7.335(5.422)$

$4.590(9.386)$

$2.737(1.410)^{*}$

$6.218(1.756)^{* * *}$

$3.536(2.810)$

$2.319(11.852)$ 
Industry dummy variables (joint significance)

Year dummy variables (joint significance)

No. of obs. (min./mn./max/firm), no. of firms

Wald chi ${ }^{2}$

Rho

$\mathrm{R}^{2}$
$99.07 * * *$

$280.52 * * *$

$2478(1 / 6.9 / 11), 358$

$598.83 * * *$

0.575

0.256
$90.83 * * *$

$280.23 * * *$

$2478(1 / 6.9 / 11), 358$

$642.46 * * *$

0.578

0.266

$* \mathrm{p}<0.1 ; * * \mathrm{p}<.05 ; * * * \mathrm{p}<0.01$ 
TABLE 3: Overview of the results of hypothesis testing (+: confirmed; -: disconfirmed)

Hypothesis

\begin{tabular}{lll}
1 & + \\
2 & + \\
3 & + \\
\hline
\end{tabular}

Test result 
FIGURE 1: Analysis of the interaction effect of advertising and corporate sustainability

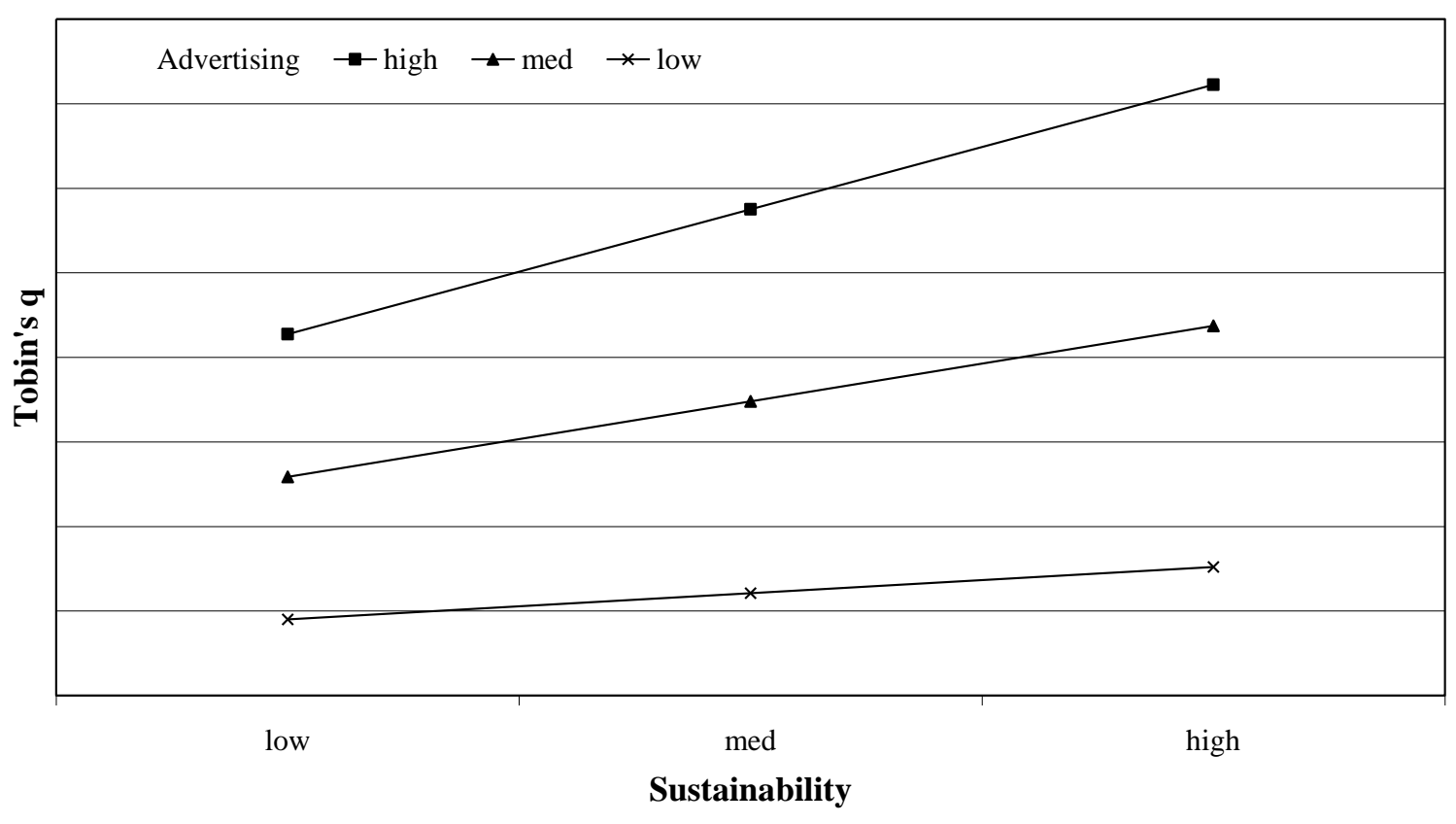

FIGURE 2: Analysis of the interaction effect of advertising and social performance

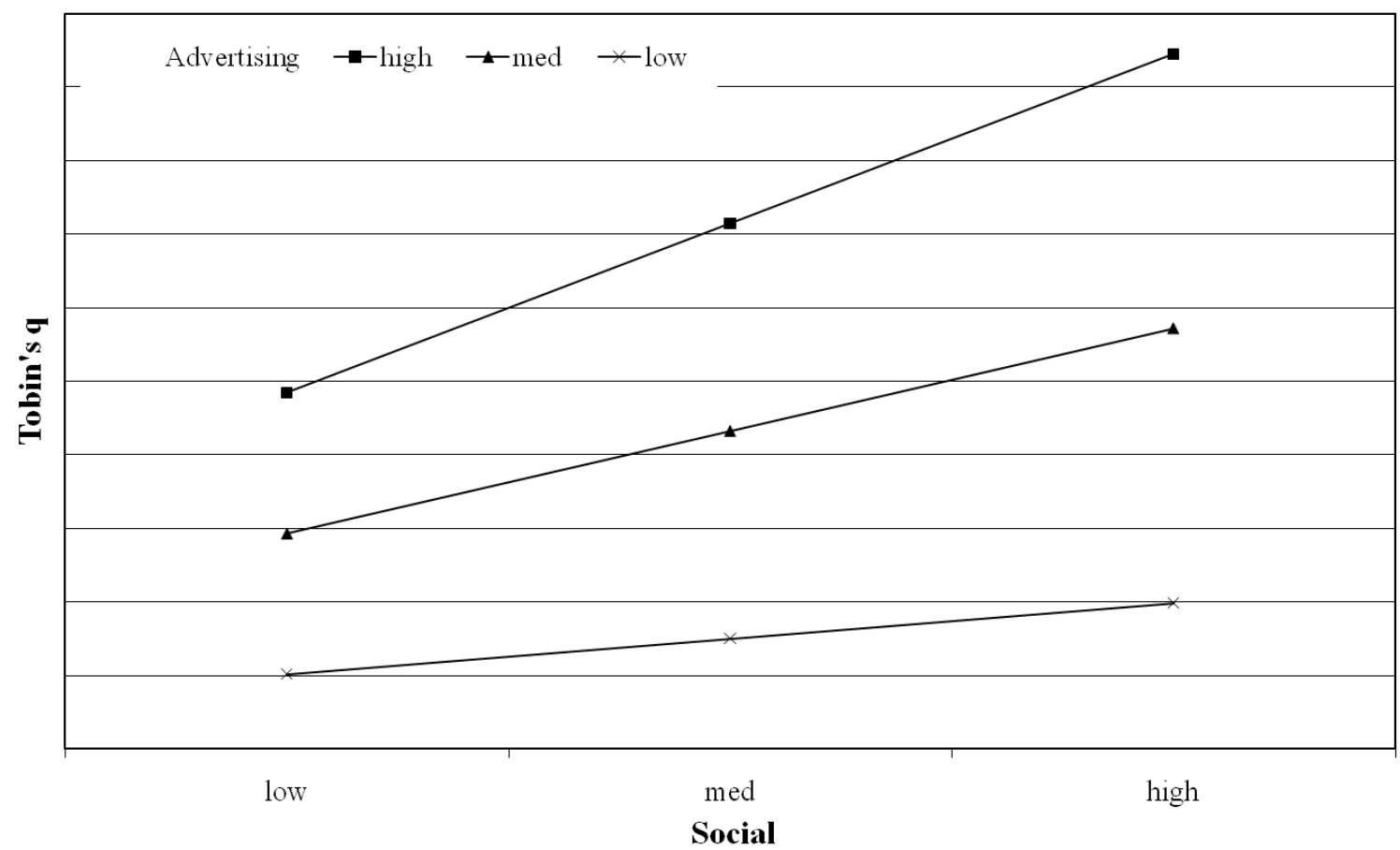


